Notes on

\title{
THE PREPARATION OF PAPERS
}

for publication in

\author{
The Journal of Hygiene \\ and in \\ Parasitology
}

\author{
By the late G. H. F. NUT'TALL
}

Under the editorial guidance of the late Professor G. H. F. Nuttall, the Journal of Hygiene and Parasitology, both of which he founded, did a great deal to raise the standard of literary workmanship in scientific papers, and both were looked on as models, upon which the publications of several scientific societies were based. In his editorial work Professor Nuttall displayed the same thoroughness as in his research, and his belief that the functions of an editor do not stop at mere supervision led him to give much of his time and energy to the correction and improvement of papers and to helping young and inexperienced workers with the publication of their work. It was his intention to publish his conclusions in one of his journals, and with this object in view he collected, in the form of notes, a large amount of information about the composition, arrangement, illustration, and printing of scientific papers. These notes are now published in book form, selected and edited by G. S. Graham-Smith and D. Keilin, the present editors of the lournal of Hygiene and Parasitology.

\section{$45.6 d$. net}

\section{CAMBRIDGE UNIVERSITY PRESS}

Printed in Britain 


\section{THE VIRUS Life's Enemy}

By KENNETH SMITH

20 Illustrations. 8 s. 6 d. net

This, the third volume in The Cambridge Library of Modern Science, deals with a subject of which little was known or imagined until very recent times, but which may yet prove to be of paramount biological, economic, and philosophical importance. It has all the interest of stories of man's courageous and imaginative research, with the added importance that a proper understanding of virus diseases and viruses is essential for the future well-being of mankind.

\section{CAMBRIDGE UNIVERSITY PRESS}

THE FABRICIAN TYPES OF INSECTS IN THE HUNTERIAN GOLLEGTION, VOLUME II

\section{COLEOP'TERA}

By ROBERT A. STAIG

31 plates in colour

$27 s .6 d$. net

(Glasgow University Publication)

This volume continues Dr Staig's systematic description and illustration of Hunter's collection of insects, made about 160 years ago and then classified by Fabricius, which was part of Hunter's bequest to Glasgow. The first volume was published in 1931 and began the description of Coleoptera, which this volume continues.

\section{CAMBRIDGE UNIVERSITY PRESS}




\section{O N T E N T S}

\section{(All rights reserved)}

JoHnson, C. G. Development, hatehing and mortality of the eggs of Cimex lectularius L. (Hemiptera) in relation to climate, with observations on the effects of preconditioning to temperature. (With 13 Figures in the Text)

BaER, Jean G. Some avian tapeworms from Antigua. (With 37 Figures in the Text)

Davies, Thomas Inwal. Three elosely related species of Aploparaksis Clere, 1903. (With 10 Figures in the Text) . . . . . . . .

RoGers, W.P. The effect of environmental conditions on the accessibility of third stage trichostrongyle larvae to grazing animals. (With 12 Figures in the text) . . . . . . . . .

Hoare, Cecrl A. On an Entamoeba occurring in English goats. (With 16 Figures in the text)

PARASITOLOGY is published about four times a year. The numbers afterwards are issued in volumes each containing four numbers.

Papers for publication should be sent to Professor D. KEnL, Sc.D., F.R.S., Molteno Institute, Downing Street, Cambridge. Other communications should be addressed to the University Press, Cambridge.

Papers forwarded to the Editors for publication are understood to be offered to PARASITOLOGY alone, unless the contrary is stated.

Contributors receive twenty-five copies of their papers free. Additional copies, not exceeding one hundred (except in special cases), may be had at cost price: these should be ordered when the final proof is returned.

The subscription price is $£ 2.15 s$. per volume (post-free), payable in advance; single numbers $18 s .6 d$. net (double number $37 s$. net). Subscriptions may be sent to any Bookseller, or to The Cambridge University Press, Bentley House, 200 Euston Road, N.W. 1.

The Cambridge University Press has appointed the University of Chicago Press agent for the sale of Parasitology in the United States of America. 